\title{
WOLNOŚĆ POD KLUCZEM: MODELE NADZOROWANIA I KARANIA MĘSKOŚCI QUEER W POWIEŚCIACH MATKA BOSKA KWIETNA JEANA GENETA I BRAT DAVIDA ALBAHARIEGO ${ }^{1}$
}

\author{
IGOR PERIŠIĆ ${ }^{2}$ \\ (Institut za književnost i umetnost, Beograd)
}

\begin{abstract}
Słowa kluczowe: męskość queer, transpłciowość, homoseksualizm, bratocentryzm (androcentryzm), Jean Genet, David Albahari Key words: queer masculinity, transgender, homosexuality, androcentrism, Jean Genet, David Albahari
\end{abstract}

\begin{abstract}
Abstrakt: Igor Perišić, WOLNOŚĆ POD KLUCZEM: MODELE NADZOROWANIA I KARANIA MĘSKOŚCI QUEER W POWIEŚCIACH MATKA BOSKA KWIETNA JEANA GENETA I BRAT DAVIDA ALBAHARIEGO. „PORÓWNANIA” 19, 2016. T. XIX. S. 83-98. ISSN 1733-165X. Nawiązując do idei zawartych w dziele Michela Foucaulta Nadzorować i karać, autor na przykładzie dwóch powieści: Matka Boska Kwietna francuskiego autora Jeana Geneta oraz Brat serbskiego pisarza Davida Albahariego, analizuje sposób manifestowania się represyjnych systemów nadzorowania i karania ze szczególnym uwzględnieniem kwestii queer. Ponadto $\mathrm{w}$ artykule poruszony został problem figury męskiej przyjaźni lub bratocentryzmu (androcentryzmu), która - zgodnie z rozpoznaniami Jacques'a Derridy zawartymi w książce The Politics of Friendship - jako filar zachodnich systemów filozoficznych wyklucza przyjaźń heteroseksualną lub kobiecą.
\end{abstract}

Abstract: Igor Perišić, FREEDOM UNDER THE KEY: MODELS OF DISCIPLINE AND PUNISHMENT OF QUEER MASCULINITY IN THE NOVELS OUR LADY OF THE FLOWERS BY JEAN GENET AND BROTHER BY DAVID ALBAHARI. "PORÓWNANIA" 19, 2016. Vol. XIX. P. 83-98. ISSN 1733-165X. This paper, based on an idea of Michel Foucault from the book Discipline and Punishment, examined how the repressive systems of discipline and punishment are present in selected literary works: on the concrete levels in the novel Our Lady of the Flowers by French author Jean Genet, and on the symbolic levels in the novel Brother by Serbian writer David Albahari, primarily

1 Tekst powstał w ramach projektu „Kulturowe teorie literatury i serbska krytyka literacka” (178013), który jest finansowany z funduszy Ministerstwa Edukacji, Nauki i Rozwoju Technicznego Republiki Serbii.

2 E-mail: perisigor@gmail.com 
in relation to the moved, queer masculinity, or more precisely the transvestite or transgender persons. At the same time, attention was given to the figure of male friendship, or androcentric figure as the basis of Western philosophy and theory, the figure that excludes heterosexual friendship and friendship among women, as described by Jacques Derrida in his book The Politics of Friendship.

W wydanej w 1975 roku książce Nadzorować $i$ karać. Narodziny więzienia Michel Foucault bada genealogię społecznych praktyk karania: od brutalnych publicznych kaźni w XVIII wieku do współczesnych więzień, na poziomie deklaratywnym będących przejawem humanizacji procesu wymierzania kary. Celem niniejszego tekstu nie jest analiza stopnia antropologicznego pesymizmu Foucaulta - badacz nie wskazuje pozytywnych rozwiązań czy też alternatywy dla przedstawionego przezeń systemu więziennictwa, który odtwarza mechanizmy przemocy, nie przyczyniając się do eliminacji zła. Zresztą, celem Foucaulta nie było wskazanie lepszego rozwiązania - badacz przyznał otwarcie, że nie jest to możliwe ze względu na fakt, że system o mniejszej szkodliwości od więziennego wciąż nie został stworzony. Dla przedstawionych tu analiz bardziej istotny jest inny wątek rozważań francuskiego filozofa, wskazujący, że represyjne systemy nadzorowania i karania są tymi, które współczesnym społeczeństwom umożliwiają całościowe definiowanie relacji pomiędzy władzą i prawdą (nowoczesny podmiot jest produktem dyscyplinarnych i performatywnych mechanizmów władzy). Rzeczywiste więzienie jest jedynie kopią więzienia już istniejącego w strukturze społecznej:

Jakże tu nie zaakceptować natychmiast więzienia, skoro zamykając, kierując na dobrą drogę, ucząc posłuszeństwa, reprodukuje ono jedynie, najwyżej z pewną przesadą, wszystkie owe mechanizmy, które funkcjonują w ciele społecznym? Więzienie - to trochę surowsze koszary, szkoła bez pobłażliwości, mroczniejsza fabryka, ale w końcu nic jakościowo różnego (Foucault 225).

Foucault stawia zatem radykalną tezę - wolność jako dobro uniwersalne nieustannie znajduje się pod kluczem, czy to faktycznym, jak ma to miejsce w więzieniach, czy to symbolicznym, w nowoczesnym społeczeństwie jako takim. W niniejszym tekście zaprezentuję sposoby manifestowania się - w różnych epokach i kulturach problemu niemożności (i jej konsekwencji) osiągnięcia przez podmiot idealnej, utopijnej lub dyskursywnej wolności.

Dosłownie pod więziennym kluczem znajduje się (autobiograficzny) narrator i bohaterowie powieści Matka Boska Kwietna (1942) autorstwa Jeana Geneta, awangardowego pisarza francuskiego, natomiast symbolicznie - dwóch głównych bohaterów powieści Brat (2008) serbskiego pisarza, postmodernisty Davida Albahariego. Cechą łączącą oba utwory jest tematyzowanie, jednak w radykalnie odmienny sposób, męskości queer.

W wydanej po raz pierwszy w 1943 roku powieści Matka Boska Kwietna Jeana Geneta, markiza de Sade'a XX wieku, bohaterowie odznaczający się nieheteronor- 
matywną męskością (męskością queer) zostają przedstawieni jako więźniowie przez autora, który nie ukrywał swojego homoseksualizmu, a wspomniane dzieło napisał w więzieniu we Fresnes. W powieściach Geneta pojawia się konkretny "Jean”, opowiadający, jak stwierdza, historię swojego „rzeczywistego życia” (Genet 122). Druga najbardziej znana powieść tego autora, Cud róży z 1943 roku także powstała w więzieniu, w Tours. Biografia Geneta, czy jego hagiografia - jeśli zaakceptujemy „wyniesienie twórcy na świeckie ołtarze” przez Jeana Paula Sartre'a, który w książce Święty Genet. Aktor i męczennik uczynił z Geneta "świętego w sercu zła” (Aćin 256) - zostaje niemal bez wyjątków stematyzowana $w$ jego obscenicznych powieściach. Życie francuskiego pisarza zawiera wszelkie elementy stosowne dla niezupełnie stosownej biografii świętego: był on (mimo wszystko drobnym) złodziejaszkiem (głównie książek), wychowankiem domów poprawczych, w późniejszym okresie stałym pensjonariuszem zakładów karnych, włóczęgą, alfonsem, męską prostytutką, fałszerzem dokumentów, legionistą, zbiegiem przed francuskim wymiarem sprawiedliwości. Przywołane miejsca i przedsiębrane działania były dla niego alternatywnymi uniwersytetami; w okresie późniejszym, kiedy ugruntował swoją pozycję jako pisarz (literatura dosłownie wybawiła Geneta od dożywotniego więzienia: Jean Paul Sartre, Jean Cocteau, Pablo Picasso i inni przedstawiciele lewicowej inteligencji uzyskali dla niego ułaskawienie), został równie osobliwym aktywistą politycznym, popierającym rozmaite metody terroru wykorzystywane przez radykalne, zarówno prawicowe, jak i lewicowe nurty polityczne.

Twórczość Geneta czerpie z tradycji łatwo rozpoznawalnych wzorców. Najłatwiej dostrzegalny jest jego związek z Charlesem Baudelairem: jako zradykalizowany poeta kwiatów zła, Matkę Boska Kwietna pisze w hołdzie zbrodni i zbrodniarzom, którzy są dla niego „ciemnymi, pięknymi kwiatami” (Genet 7). Posługując się metodą upoetyczniania skatologicznych i innych hipernaturalistycznych czynności Genet, przy pomocy rabelaisowskiego rozpasania, trawestując dyskurs religijnej duchowości oraz wykorzystując figurę blasfemii Joyce'a, tworzy swoistą estetykę zła. W jego twórczości widoczne są także wpływy François Villona, Pierre'a de Ronsarda i Marcela Prousta a także Fiodora Dostojewskiego i Alberta Camusa. Jeśli wierzyć biografiom, właśnie kradzież książki Prousta $W$ cieniu zakwitających dziewcząt zaprowadziła Geneta do więzienia (Aćin 255).

Tytułowa postać - Matka Boska Kwietna - to młody złoczyńca, który nazywa siebie oksymoronicznym mianem "niewinnego zabójcy”. Jego ofiarą jest "bezwartościowy"starzec, by posłużyć się analogią do słynnej „staruchy”, bohaterki Zbrodni i kary. Motyw zabójstwa odsyła zarówno do twórczości Dostojewskiego, jak i (jako antycypacja) do powieści Obcy Alberta Camusa, opublikowanej w roku, w którym powstaje powieść Geneta.

Niezależnie od literackich odniesień, twórczość Geneta trudno jednoznacznie usytuować $\mathrm{w}$ obrębie $(\mathrm{u}) z n a n y c h$ tradycyjnych poetyk, ponieważ mamy tu przede wszystkim do czynienia - o czym pisała Hélène Cixous - $\mathrm{z}$ błyskotliwym 
przykładem écriture feminine (Cixous 151). W tym kontekście dla dalszego porządku wywodu istotny jest sposób, w jaki Genet rozwiązuje problem specyfiki męskiej narracji. Opowieść o transwestytach ujęta zostaje w formę narracji transgenderowej:

Będę wam opowiadał o Boskiej [transpłciowa prostytutka, jeden z głównych bohaterów/bohaterek powieści - I.P.], mieszając, zależnie od nastroju chwili, rodzaj męski z żeńskim, a jeśli zdarzy się w trakcie tej opowieści konieczność mówienia o kobiecie, postaram się o takie wyjście, o taki wybieg czy sprytną sztuczkę, by nie powstała jakakolwiek niejasność (Genet 18).

W powieści Geneta spotkanie narratora $\mathrm{z}$ tożsamościami niestabilnymi, queer lub transseksualnymi, nie wywołuje u niego żadnej konfuzji, narrator nie ma żadnych dramatycznych wątpliwości w kwestii przypisania postaciom rodzaju gramatycznego, jak ma to miejsce w powieści Albahariego Brat. Narrator Matki Boskiej Kwietnej nie "piętnuje” takich tożsamości, dotrzymując obietnicy, że opowiadając o swoich bohaterach transwestytach, nie będzie przywiązywał uwagi do kwestii rodzaju gramatycznego. $\mathrm{Z}$ tego powodu w całej powieści dosyć niekonwencjonalnie posługuje zarówno rodzajem męskim, jak i żeńskim³.

Komplikacje związane $\mathrm{z}$ określeniem płci, momentami komiczne, są przejawem empatycznego stosunku autora do bohaterów, a nie chęci ich wyśmiania. Dobrym przykładem jest sytuacja, w której Boska (będąca głównym i zarazem tytułowym bohaterem powieści, dzięki któremu powieść nabiera kampowego charakteru), do tej pory "pasywny" homoseksualista, zakochuje się w kruchej i kobiecej Matce Boskiej Kwietnej i pragnie stać się „męska”:

Czuła, że staje się mężczyzną. Szaleńcza nadzieja dodała jej mocy, krzepy i wigoru. Czuła, jak rosną jej mięśnie, czuła, jak wyłania się ze skalnego bloku - niczym niewolnik wyciosany przez Michała Anioła. Nie poruszając ani jednym mięśniem, ale napinając się $\mathrm{z}$ całej siły, toczyła wewnętrzną walkę, podobnie, jak Laokoon mierzy się z gadem wykręcając mu cielsko. A potem, wciąż śmielej, z rękami i nogami już z pełnokrwistego ciała, chciała boksować się, walczyć, ale prędko oberwała po gębie na bulwarach, bo kroiła i oceniała swoje ruchy nie według ich skuteczności, lecz według założeń pewnej estetyki, która miała z niej uczynić żula mniej lub bardziej rycerskiego. [...] ... a potem, przypominając sobie nagle, że powinna być tak męska, żeby uwieść nawet zabójcę, przechodziła do burleski, i ta podwójna maska przydawała jej aurę niezwykłości, czyniła z niej płochliwego błazna w mieszczańskim stroju, coś w rodzaju zgorzkniałej wariatki (Genet 54-55).

3 Ja również $\mathrm{w}$ tego typu sytuacjach nie będę rygorystycznie zwracał uwagi na rodzaje gramatyczne, gdyż utrudniłoby to odbiór tekstu. Podwójne, męsko-żeńskie nazewnictwo będzie używane tylko wtedy, kiedy niezbędne okaże się podkreślenie transpłciowego charakteru postaci, o których mowa. 
Mamy tu do czynienia nie tylko z kłopotami z określeniem rodzaju gramatycznego, ale obserwujemy konkretne problemy Boskiej z opowiedzeniem się po stronie jednej płci. Co więcej, jej wybór ma charakter bardziej estetyczny (zewnętrzny), niż egzystencjalny (wewnętrzny). Źródłem komizmu jest właściwie fakt, że w krótkotrwałym przebłysku karnawalizacji tożsamości Boska usiłuje być tym, kim nie jest, być wyłącznie jednym, podczas gdy jako transwestyta zawsze pozostaje zarówno jednym, jak i drugim. Z tego właśnie powodu próba bycia wyłącznie „mężczyzną" skazana jest na niepowodzenie. Ta substancjalna dwoistość, zdaniem narratora, nie ulega wątpliwości: „ale Boska jest przecież także mężczyzną” (Genet 103), stwierdza, by później obszerniej skomentować ten fakt:

I wtedy natychmiast Boska znów stał się tą Boską, którą przestała być, gdy schodzili ulicą Lepic; bo przecież, chcąc myśleć szybciej i sprawniej, odczuwała jako „kobieta”, a myślała jako „mężczyzna”. Można by przypuszczać, że skoro powróciła tak spontanicznie do swej prawdziwej natury, Boska była mężczyzną skrytym pod makijażem, zniekształconym udawanymi gestami; ale nie chodzi tu o powrót do języka dzieciństwa, języka ojczystego, jak to ma miejsce w przełomowych godzinach życia. Aby myśleć z precyzją, Boska nie powinna nigdy wypowiadać swoich myśli głośno, dla siebie samej. Bez wątpienia, zdarzało się już Boskiej powiedzieć do siebie na głos: „Jestem biedną, małą dziewczynką", ale czując, że to mówi, przestawała być o tym przekonana, a wypowiadając te słowa przestawała już w ten sposób myśleć. W obecności, na przykład, Mimozy [jeszcze jeden transwestyta i transpłciowa prostytutka - I.P.] zdarzało się jej pomyśleć "kobieta” w odniesieniu do spraw ważnych, lecz nigdy zasadniczych. Jej kobiecość była zatem tylko maskaradą. Jej ciało - jego organy - nie pozwalały jej myśleć o sobie w pełni jako o „kobiecie”. Myśleć to znaczy działać. Lecz aby działać, należy pozbawić się frywolności i osadzić swoją myśl na solidnym cokole. I wtedy przyszło Boskiej z pomocą pojęcie solidności, które łączyła z pojęciem męskości, głównie za sprawą gramatyki. Żeby określić stan, jaki odczuwała, Boska ośmieliła się użyć rodzaju żeńskiego, ale nigdy nie używała tej formy, kiedy mówiła o konkretnym działaniu. Wszystkie jej sądy i opinie „kobiece" były w istocie osądami poetyckimi. Więc tylko wtedy była Boska sobą (Genet 108).

Powyższy cytat stanowi egzemplifikację awangardowego charakteru dzieł Jeana Geneta, który nie znając późniejszych genderowych dyskursów emancypacyjnych i teorii queer, wykorzystywał narrację pozbawioną dyskursywnych mechanizmów nadzorowania i karania oraz poddawał refleksji dylematy tożsamości gender/queer, także współcześnie stanowiące przedmiot ożywionych dyskusji. Pojęcie queer konotuje wszystko to, co przeciwne heteronormatywności, czyli normom ustalonym na bazie heteroseksualności. Idea ta zakłada niestabilność tożsamości, w odróżnieniu od stabilnych (do pewnego stopnia) tożsamości lesbijskich, gejowskich, biseksualnych i transpłciowych, które są kształtowane przez strategie normatywizujące (Freccero 49). Teorie queer reprezentują politykę seksualności antytożsamościowej. Dekon- 
strukcja esencjonalistycznych założeń ustalonej identyfikacji gender, w koncepcjach queer służy deprecjonowaniu uzyskanej w ten sposób wolności, która zostaje wykorzystana do naturalizacji nowych zjawisk (Perišić 388). Queer bywa używany do opisu „niedomkniętej konstytutywności, której cechą nie jest sama tożsamość, ale antynormatywne pozycjonowanie w odniesieniu do seksualności" ${ }^{4}$ (Jagose 98). Nie ulega wątpliwości, że Boska jest osobą pozycjonowaną nieheteronormatywnie, tj. osobą o tożsamości queer oraz transwestytą. Jednak jej transpłciowość nie jest do końca określona i również w tym znaczeniu okazuje się osobą o podwojonej identyfikacji queer - chociaż Boska wygląda jak kobieta, to myśli ona i działa jak mężczyzna, natomiast pragnienie, by stać się kobietą w sensie anatomicznym (transseksualizm), nie jest nawet zasygnalizowane. Mamy tu do czynienia $\mathrm{z}$ transgresywnym pozycjonowaniem tożsamości płciowej, w której binarna logika „albo/albo” przezwyciężona zostaje poststrukturalistyczną czy też rizomatyczną logiką „,i/i”, gdzie jedno zawsze zostawia miejsce innemu. Taka tożsamość jest bliższa płynnej tożsamości queer niż identyfikacji gejowskiej czy homoseksualnej. Z drugiej strony Boska jako anatomiczny mężczyzna jest wyraźnie przedstawiona jako homoseksualista. Jeśli zatem potraktowalibyśmy tę próbę wskazania tożsamości w kategoriach jej ostatecznego dookreślenia, byłby to powrót do sztywnych kategoryzacji identyfikacyjnych. Ten mężczyzna w sensie anatomicznym, z pewnością nie jest jednak mężczyzną, który chce performatywnie zatwierdzić swoją płeć. Przeciwnie, jego wygląd zewnętrzny, chociaż jest "maskaradą", stanowi następstwo świadomej decyzji, by w heteoronormatywnym świecie odgrywać inną rolę płciową. Ponieważ feminizacja mężczyzny uznana jest za akt bardzo silnie wpływający na destabilizację ograniczeń płciowych (Jagose 39), odgrywanie takiej roli w odniesieniu do porządku patriarchalnego okazuje się jednym z działań o dużym potencjale subwersyjnym. Ostatecznie, precyzyjne wskazanie tożsamości Boskiej oraz pozostałych bohaterów/ bohaterek powieści nie jest ostatecznym celem niniejszych rozważań. Próba wskazania dokładnej nazwy byłaby działaniem zmierzającym do (medycznego, psychologicznego lub nawet teoretycznoliterackiego) nadzorowania męskości queer, a więc jeszcze jednym aktem dyskursywnej przemocy wobec niej.

Oprócz transgresji płciowych, w powieściach Geneta mamy do czynienia także z transgresją tradycyjnych norm moralnych. Rozpusta i cudzołóstwo pojawiają się jako rezultat duchowej niemocy osiągnięcia cnoty i w tym sensie paradoksalnie stają się one czynami zaświadczającymi o duchowej elegancji grzechu w odróżnieniu od dwulicowej czystości opartej na sakralnych instytucjach mocy. Aleksandra Mančić zauważa, że chociaż widoczne jest dążenie Geneta, by stać się "nieludzkim” w nietzscheańskim sensie, Jean Genet gloryfikuje zło. Choć zasługuje na karę, nie znaczy to, że nie ma w nim piękna i uwodzicielskiego czaru, zaś

4 "an open-ended constituency, whose shared characteristic is not identity itself but an antinormative positioning with regard to sexuality". 
konkluzja dotycząca akceptacji zła w pozamoralnym sensie prowadzi badaczkę do stwierdzenia, że: „[Genet] tworzy chrześcijańską legendę bez Boga, w której do świętości prowadzi tradycyjna droga afirmacji wszelkich poniżeń i wszelkiego cierpienia" (Mančić 340). Niektórzy psychoanalitycy uznają nawet, że skłonność do występku jest tylko drugim obliczem pragnienia cnoty. Jeśli przyjrzymy się jego genezie, naczelne Dobro, wywodzone przez de Sade'a i Jeana Geneta z psychicznej potrzeby przyjemności, jest identyczne z fundamentalną chrześcijańską tezą o powstaniu Dobra w następstwie udaremnienia realizacji takich pragnień. Według Christophera Lane’a kontynuującego myśl Jacquesa Lacana rozpusta i asceza, przynależą do tego samego radykalnego pola świadomości, w którym konstytuuje się etyczność pozbawiona sygnałów wartościujących (Lane 325-351). Za pomocą stwierdzenia, że Boska całe życie była zmuszona kochać to, do czego czuła wstręt, ponieważ świętość "to przecież zaparcie się siebie” (Genet 70), narrator uświęca bohaterkę, naprowadzając w ten sposób czy telnika na trop paradoksalnej wolności. Doświadczają jej także bohaterowie, którym nie pozostaje nic innego, jak uznać więzienie za przestrzeń psychicznej wolności, w której symboliczne systemy społecznego nadzorowania i karania zostają zlekceważone.

Transgresje tradycyjnych wyobrażeń, których dokonał Genet, obejmują również repertuar relacji między mężczyznami, które nie zostają obciążone balastem kulturowych ról typowych dla społeczności heteronormatywnych czy patriarchalnych. Relacje te pozostają niemal w zupełności poza modelem opisanym przez Jacques'a Derridę w książce The Politics of Friendship (Polityki przyjaźni). Francuski filozof twierdzi, że w zachodnich systemach filozoficznych od ich początków dominuje jedna figura przyjaźni, reprezentująca „,androcentryczną, fraternistyczną, a więc familiarystyczną, etniczną i nacjonalistyczną, a więc genetystyczną i fallogocentryczną zasadę" (Derrida 2001: 9), którą chciałby zdekonstruować. Figura brata jest tu szczególnie interesująca jako fundament androcentrycznej konfiguracji pola politycznego (Derrida 2005: VIII), ponieważ będąc zawsze w sensie symbolicznym potencjalnie homoseksualna, wyklucza $z$ takiego filozoficznego paradygmatu kobietę, bez względu na to, czy mowa o figurze przyjaźni pomiędzy kobietami (siostrzeństwie), czy też o heteroseksualnej przyjaźni damsko-męskiej. Przykładowo, według Derridy, Michel de Montaigne:

[...] odrzuca heteroseksualną przyjaźń, wykluczając boską więź, która nie łączy dwóch meżczyzn, dwóch "towarzyszy” w sposób figuratywny, czy też poprzez braterską przysięge, jeżeli nie jest to więź tzw. naturalnego braterstwa. Relacja pomiędzy dwiema towarzyszkami, czy też pomiędzy towarzyszką i towarzyszem, nigdy nie może dorównać swojej modelowej postaci, relacji dwóch towarzyszy. Ten, któremu towarzyszę, jeżeli jest on moim przyjacielem, to mężczyzna ${ }^{5}$ (Derrida 2005: 180).

$5, \ldots[$,... bears only an 'imaginary resemblance' to this 'holy bond' of sovereign friendship, silently 
Genet w swojej powieści dokonuje dekonstrukcji tak pojmowanego androcentryzmu i bratocentryzmu - „przyjaciel”, implikujący sensy metafizyczne i symboliczne, które w historii Zachodu funkcjonują jako społecznie pożądane, jest $\mathrm{u}$ francuskiego pisarza nieobecny. Genet nie potrafi zaprzestać postrzegania męskiego przyjaciela w sposób jawnie (a nie skrycie) homoerotyczny i homoseksualny:

Bo jeśli nigdy nie wiedziałem, czym, w istocie, może być przyjaźń pomiędzy dwoma mężczyznami, jakie wzajemne wibracje wzbudzić może w ich sercach (albo na ich skórze), $\mathrm{w}$ więzieniu odkrywam niekiedy pragnienie braterskiej przyjaźni, ale zawsze z mężczyzną w moim wieku, pięknym i mającym do mnie całkowite zaufanie, który byłby wspólnikiem mych miłosnych uniesień, moich kradzieży i przestępczych pragnień; lecz nie mówi mi to wiele o samej przyjaźni, o jej tajemnej intymności czy o zapachu obu przyjaciół, bo jestem wtedy wówczas samcem, który wie, że tak naprawdę nim nie jest (Genet 37).

Chociaż czasem pragnie braterskiej przyjaźni, narrator jest świadomy, że spełnienie tego życzenia jest $w$ praktyce niemożliwe i $w$ tym sensie nie jest on prawdziwym „mężczyzną". Słowo „przyjaciel” w powieści Matka Boska Kwietna jest zawsze zarezerwowane dla faktycznych lub nieurzeczywistnionych kochanków. Nawet gdyby został odnaleziony prawdziwy przyjaciel, musiałby być piękny i pozostawać w pewnym homoerotycznym związku z narratorem, tak aby był wyczuwalny jego "zapach", co stanowi metonimię fizycznej atrakcyjności. Opisując jednego z epizodycznych bohaterów, Genet posiłkuje się ironią, wymierzoną w jego własny sposób kreowania męskich postaci, nigdy nie będących "prawdziwymi” przyjaciółmi, lecz tylko obiektami erotycznego pragnienia: „Był przystojny jak wszyscy samcy $w$ tej ksiażce - samcy silni i giętcy, nieświadomi swego wdzięku" [wyróż. - I.P.] (Genet 70). W ten sposób zostają unieważnione hierarchie ustalone, by nadać figurze przyjaciela status heteronormatywności. Pośrednio zaś narrator, opuszczając bezpieczne schronienie zachodniej tradycji dyskursywnej, uformowanej na „duchowych" modelach andro- i bratocentryzmu, rozpoczyna niepewną, cielesną, narracyjną przygodę homoseksualnej i homoerotycznej dekonstrukcji takich wzorców.

W powieści Davida Albahariego Brat z 2011 roku mamy do czynienia z odmienną dialektyką męsko-męskiej przyjaźni lub bratocentryzmu, bowiem na poziomie konstrukcji narratora i postaci zostaje zachowana androcentryczna matryca zachodniej metafizyki. Przyczyną tragedii głównego bohatera powieści, Filipa, jest obsesja, by nie dopuścić do przemiany jego niespodziewanie odnalezionego brata $\mathrm{w}$ siostrę. $\mathrm{Z}$ powodu nacisków władz komunistycznych po protestach studenckich

dismisses heterosexual friendship, excluding a holy bond that would unite anyone other than two men, two male 'companions', in the figure and the oath of friendship, if not in so-called natural fraternity. The bond between female companions or between a woman-friend and her companion could never be equal to its model: the bond of two male companions. The person who accompanies me, if he is the friend of the friend that I am, is a man." 
w 1968 roku, w których aktywnie uczestniczył ojciec bohaterów, wykładowca akademicki, oboje rodzice zostali zmuszeni - przez wzgląd na swoje bezpieczeństwo, ale i wizję lepszej przyszłości jednego z dzieci - do wyrzeczenia się syna (Roberta) i oddania go do adopcji w Argentynie. Bohater dowiaduje się o wszystkich szczegółach swojego pochodzenia (a także o istnieniu siostry, która zginęła jako dziecko w wypadku samochodowym) i przyjeżdża do Serbii, aby odnaleźć brata.

Główny bohater powieści Brat, w odróżnieniu od narratora Matki Boskiej Kwietnej, nie tylko w żaden sposób nie kwestionuje represyjnej bratocentrycznej i androcentrycznej podstawy zachodniej tradycji filozoficznej, ale wręcz obsesyjnie usiłuje ją potwierdzić. Przejawia oznaki patologicznego pragnienia utożsamienia się z androcentryczną męskością, demaskowaną przez jego własną wypartą homoseksualność, od której stara się na wszelkie sposoby uciec, poprzez zarówno symboliczne, jak i w pewnej mierze faktyczne unicestwianie męskości, która jest mu obca, a jednocześnie podświadomie bliska. Istniejący brat nadspodziewanie szybko wypełnia pustkę spowodowaną brakiem nieżyjącej siostry, wskazując na to, że androcentryczna miłość jest dla Filipa ważniejsza i bardzo szybko rekompensuje nieobecną kobiecość. Również próby wyobrażenia sobie przebiegu spotkania z bratem - dopóki Filip żywił się myślą o "prawdziwym” bracie-mężczyźnie - pełne są dowodów na to, że męska miłość jest dla Filipa jeśli nie w większym, to przynajmniej w równym stopniu ważna, co miłość heteroseksualna i - potencjalnie - homoerotyczna. Perspektywa poznania brata wywołuje $\mathrm{w}$ nim symptomy zbliżone do tremy przed pierwszą randką z dziewczyną: drżą mu kolana, obficie się poci, z wrażenia zaś „zaczyna czuć mrowienie w palcach i nie wiadomo, gdzie jeszcze je poczuje, zanim się spotkają" (Albahari 54). Uwaga o mrowieniu może mieć charakter aluzji o charakterze seksualnym, ale może też być całkowicie pozbawiona takiego podtekstu, dlatego nie będziemy jej szczegółowo analizować. Trzeba jednak zwrócić uwagę na ogólne pobudzenie bohatera, które towarzyszy spotkaniu z brakującą męskością. Gdy okazuje się, że Robert jest osobą transpłciową (transwestytą) i zamierza zmienić płeć biologiczną, aby stać się transseksualistą - Alisą, Filipa wypełnia poczucie braku kobiecości:

Przed nim, powiedział, pojawiała się tylko pustka i im bardziej starał się skupić na odpowiedzi Roberta, jak i na jego gestach, tym bardziej pusta stawała się ta pustka, aż w końcu wypełniła go całego, chociaż może dokładniej należy powiedzieć: opróżniła go całego, przemienił się w swoją własną nieobecność i wszystko, co czuł, jedyne, co czuł, to strach, że nie uda mu się wrócić do dawnej postaci, na zawsze zostanie wypełniony pustką, dziurawy, nierealny i niemy (Albahari 154).

Bohater odczuwa jedynie chęć powrotu do ustalonego porządku, do swojego pragnienia androcentrycznej i bratocentrycznej jedności, gdyż bez męskiej, homoerotycznej zasady życie Filipa jest pozbawione sensu. Akceptuje on brata tylko w jednej krótkiej chwili, kiedy zachwyca się jego „męską” odwagą podczas bójki stoczonej 
przez niego z agresywnym gościem, wyrażającym, za pomocą rękoczynów, dezaprobatę dla transgenderowego performance'u wykonanego przez Roberta/Alisę w celu ujawnienia własnej tożsamości. Po pobiciu, śmiertelnym, jak się później okaże, Filip nie przychodzi bratu/siostrze z pomocą; co więcej, zabiera Roberta/Alisę do swojego mieszkania, gdzie praktycznie pozwola mu/jej umrzeć w wannie. Podczas jednego z pierwszych ataków rozbestwionego gościa restauracji $\mathrm{w}$ Zemunie:

Robert podniósł głowę, rozejrzał się wokół, wzruszył ramionami i usiadł za stołem. I nie wie, powiedział Filip, dlaczego nazywa go Robertem, może powinien nazywać go Alisą, gdyż kiedy to się działo, właściwie był Alisą, a nie Robertem, ale to imię nie mogło mu przejść przez usta, chociaż $\mathrm{w}$ jednym momencie, tylko w ty m momencie, powiedział, pomyślał, że jest dumny ze swojej siostry. Pomyślał: „Jestem dumny ze swojej siostry", powiedział, ale od razu odsunął tę myśl i powiedział do siebie: „Alisa jest moim bratem" (Albahari 165, podkr. - I.P.).

Choć przez chwilę fizyczna konfrontacja Roberta/Alisy z homofobią - czyn, na który Filipowi zabrakło odwagi - wzbudza entuzjazm tego ostatniego, to jednak szybko porzuca on myśl o akceptacji tożsamości brata. Kiedy Robert/Alisa zostaje pobity na śmierć, Filip stwierdza, że „każdy dostaje to, na co zasłużył” (Albahari 191), utożsamiając się $\mathrm{z}$ agresorami.

W powieści Albahariego androcentryczne, męsko-męskie są także instancje narracyjne. Główny bohater - mieszkający w Serbii Filip - otrzymuje list, z którego dowiaduje się, że ma brata, który dorastał w Argentynie. Opowiada o tym anonimowemu przyjacielowi, który jest także narratorem powieści, przy czym pomiędzy nim a Filipem rodzi się intrygująca relacja (potencjalnie homoerotyczna ze strony Filipa). Jak zaznacza Tatjana Rosić, mnożenie punktów narracji jest strategią typową dla twórczości prozatorskiej Albahariego, jednak podwojona tożsamość narracyjna zyskuje $\mathrm{w}$ powieści Brat zupełnie nowe znaczenie. Wypowiedzi anonimowego narratora i Filipa (narrator referuje wyznanie Filipa) bez przerwy "przekształcają się i przechodzą jedna w drugą, podejmując wysiłek osiągnięcia zdradliwej i niemożliwej homogenizacji męskiej tożsamości" (Rosić 324).

Aby sportretować „paranoiczność samooglądu w homogeniczym Innym”, Albahari posługuje się specyficzną konstrukcją zdań (podwajającą męsko-męskie głosy według formuły: „powiedział Robert”, „powiedział Filip”), stanowiącą „ironiczną egzemplifikację lustrzanej relacji męskich głosów tej wspólnoty" (Rosić 322). Takie androcentryczne i ironiczne podwajanie pozycji narratora Rosić łączy z dialektyką przyjaźni Derridy:

Jeżeli w ten ciąg identyfikacyjny włączymy również samego narratora, zobaczymy, że relacja narrator-Filip-Robert/Alisa wskazuje na profesjonalne, państwowe i polityczne przesłanki braterstwa, które tworzą, według Derridy, dwaj przyjaciele plus jeden. Cier- 
pliwy główny narrator jest również pisarzem: Filip, Robert/Alisa i on należą do tej samego cechu, tego samego profesjonalnego klanu, tego samego „braterstwa”. Można powiedzieć, że milczący narrator i Filip są w tej perspektywie lustrzanymi postaciami, które w milczeniu łączą swoje siły, pozycjonując na moment obywatelską figurę państwowotwórczego i afirmatywnego politycznie braterstwa [...]. Chociaż przed końcem powieści ta lustrzana figura braterstwa zostaje zdemaskowana jako złudny i tymczasowy sojusz, który poprzedza ostateczne rozejście, jest oczywiste, że Filip dąży do innego, „prawdziwszego" zjednoczenia. Wydaje się, że zamiast akceptować problematycznego brata-będącego-siostrą, chętniej z bezimiennego przyjaciela-narratora uczyniłby prawdziwą bratnią duszę, tego przyjaciela, który w zachodniej kulturze konstytuuje figurę męskiego braterstwa z całym jej kulturologicznym i ideologicznym zapleczem (Rosić 328-329).

Jak błyskotliwie zauważyła Tatjana Rosić w drugiej części przywołanego fragmentu, Filip chce od narratora „czegoś więcej”, a zatem co najmniej tej społecznie pożądanej, „prawdziwej” męsko-męskiej przyjaźni. Nie otrzymuje jednak satysfakcjonującej informacji zwrotnej, co ujawnia występująca w ich relacji niewspółmierność - narrator nie odwzajemnia w równej mierze potrzeby bliskości Filipa, któremu po rozwodzie z żoną nie przychodzi do głowy, że mógłby wypełnić tę pustkę kobietą:

Wierzy, powiedział, że rozumiem jego ekscytację, jego dreszcz emocji, to jego pragnienie, aby wszystko to ze mną podzielić, skoro nie ma nikogo innego, komu mógłby się zwierzyć, i od kogo mógłby, co o wiele ważniejsze, otrzymać wsparcie i zrozumienie, tak bardzo potrzebne osobie, która, jak on, jest sama na świecie (Albahari 65).

Narrator funkcjonuje w powieści jako everyman (nie zostaje nazwany, nie jest też obdarzony żadną znaczącą cechą charakteru) lub obojętny słuchacz, chociaż, jak pokazałem, Filip być może chciałby postrzegać tę więź inaczej. Zdecydował się on - jak relacjonuje narrator - „przyjść i wszystko mi opowiedzieć, pomimo tego, że żaden z nas nie mógł sobie przypomnieć, kiedy ostatnio się widzieliśmy" (Albahari 20-21). Celem takiego usytuowania narratora jest wyodrębnienie go jako dyskretnego, ale niebezpiecznego głosu społeczeństwa poddanego normalizującym mechanizmom represji. Już na pierwszej stronie powieści zostaje zaprezentowany mechanizm działania takiej świadomości - po informacji, że Filip nawet nie spojrzał na kopertę z otrzymanym listem, narrator dodaje: „jak zapewne uczyniłby każdy z nas" (Albahari 5), co sprawia, że deklaruje się on jako podmiot pogodzony z faktem istnienia pewnych ustalonych, społecznie akceptowalnych zachowań.

Nikola Đoković, w interesującej analizie powieści Brat, zauważa, że przeniesienie fokalizacji z narratora na Filipa już w pierwszym zdaniu powieści sygnalizuje „zaskoczenie mówiącego, dostrzeżone przez nienazwanego narratora, który nie decyduje się jednak, aby je skomentować i pozostawia scenę narracji opowiadającemu i aktorowi opowieści, Filipowi”. Taki zabieg unaocznia „zachwianie równowagi czy 
też swoiste «nielegalne» wtargnięcie w strefę komfortu mówiącego oraz głównego bohatera" (Đoković 134-135). Zatem już na początku powieści otrzymujemy sygnał, że narrator percypuje relacjonowane przez Filipa wydarzenia w kategoriach dziwności, obcości - a zatem queer, przez co dystansuje się od przedstawionych wydarzeń i stawia się „poza” społecznymi mechanizmami nadzorowania i karania.

Oprócz narratora jako reprezentanta opinii publicznej zadanie nadzorowania zostaje powierzone opinii publicznej, nieokreślonej homofobicznej masie z restauracji Brioni, która podejmują próbę surowej resocjalizacji Roberta/Alisy. Gość lokalu, który inicjuje napad na Roberta i Filipa, nazywa ich "pedałami”, natomiast (auto)homofobia Filipa ujawnia się jako reakcja na przejawy intymnej bliskości między nim i Robertem:

Wie, powiedział, jak się u nas postrzega dwóch facetów trzymających się za ręce, a zwłaszcza dwóch facetów trzymających się za ręce, z których jeden z nich płacze, ale nie zwracał na to uwagi, chociaż w pewnym momencie pomyślał, że wstanie i krzyknie tak, aby usłyszała go cała knajpa: „To mój brat!”(Albahari 93).

Bohater nie próbuje uwolnić się od oskarżeń tłumu o homoseksualizm i nie staje w obronie brata/siostry. Nie podejmuje także żadnych działań, by udaremnić brutalny napad na Roberta/Alisę, kiedy sytuacja staje się naprawdę niebezpieczna. Taksówkarza, który pomaga mu umieścić w samochodzie śmiertelnie rannego Roberta/ / Alisę, zaprasza do restauracji, podobnie jak ludzi, którzy pomagają mu przetransportować do mieszkania brata/siostrę, umierającego/umierającą w wannie. Kiedy goście wychodzą, zasypia "głębokim snem" (Albahari 180). Jak konkluduje Nikola Đoković:

Odwlekanie Filipa symbolizuje pewien całościowy system, w którym życie (osoby „wątpliwej" pod względem płci biologicznej i kulturowej) nie może uzyskać legitymizacji, statusu niezwłoczności i priorytetowości, gdyż obywatelski porządek jest „fantasmagorycznie" spowolniony i zbiurokratyzowany, czym w zasadzie legitymizuje swoją własną groteskowość i „zwichnięcie”; uznaje on irracjonalność za racjonalną taktykę, efektywność i precyzję, a dyskryminację innego unieważnia w imię poszanowania dla procedur i hierarchii (Đoković 153).

Mamy tutaj zatem do czynienia ze strategią tożsamościowej mimikry, której celem jest upodobnienie do zbiorowości. Wszelkie wahania Filipa wynikają z utożsamiania się z reprezentującymi homofobiczny tłum postaciami, które udzielają mu obywatelskiego poparcia (kiedy taksówkarz poklepuje go po plecach, mówiąc, że wszystko będzie w porządku - będzie w porządku, gdyż opinia publiczna „przyzwala" na ukaranie Roberta/Alisy, a represyjny porządek społeczny udziela poparcia Filipowi, który doprowadza do śmierci brata, opóźniając zabranie go do 
szpitala). Tym samym Filip uczestniczy w działaniach represyjnego społeczeństwa, dyskryminującego odmienność płciową za pomocą strategii odwlekania procedur.

Aby zanegować poczucie winy, które pojawia się, bez względu na „rozpłynięcie się" w głosie represyjnej opinii publicznej, Filip posługuje się między innymi taktyką estetyzacji zła: postrzega całe wydarzenie jako część tragedii, którą analizuje, wzorując się na arystotelesowskiej teorii tego gatunku. Celem wprowadzenia do tekstu powieści fragmentu refleksji Arystotelesa nie jest, jak miało to miejsce we wcześniejszych utworach Albahariego, typowo postmodernistyczny, autopoetycki namysł nad aktem pisania ${ }^{6}$, ale zastąpienie problemu odpowiedzialności gatunkowo-teoretycznym fantazmatem. Umieszczając tę refleksję tuż przed opisem tragicznych wydarzeń, pisarz przygotowuje bohatera do tego, by ten w swojej obywatelskiej bojaźliwości, $\mathrm{w}$ razie niefortunnego finału spotkania $\mathrm{z}$ bratem, dokonał sublimacji tego wydarzenia w jeszcze jedną historię z cudzego życia:

Brat, którego widział po raz pierwszy w życiu, powoli znikał sprzed jego oczu, a on szukał odpowiedzi w rozmyślaniach o Arystotelesie. Coś tu było nie w porządku, powiedział, i powinien był zganić się bardziej zdecydowanie, ale było za późno, już zaczął przywoływać fragmenty Poetyki i patrzyć na siebie i na Roberta jak na wzorcowych bohaterów Arystotelesowskiej tragedii. Nie mógł, oczywiście, przypomnieć sobie wszystkich tez Arystotelesa, jego znajomość antycznych klasyków zawsze była niepełna, powiedział, ale był całkowicie pewien, że gości i pracowników restauracji Brioni można uznać za chór, Brioni za scenę, zaś wszystkich obecnych za publiczność. Tworzyli widowisko, które sami oglądali w czasie, gdy powstawało (Albahari 148-149).

Postrzegając siebie jako uczestnika przedstawienia, estetyzując zło, Filip chce ukryć to, co $\mathrm{w}$ powieści przedstawione jest jako morderstwo przez zaniechanie. W tym momencie rozważania Filipa tracą charakter metapoetycki, stają się fałszywym wybiegiem retorycznym. Filip nie uratuje brata, ponieważ obarcza go odpowiedzialnością za zaistniałą sytuację:

6 Postmodernistyczna twórczosć Albahariego, jak zauważa Sylwia Nowak-Bajcar, ulega przemianom w latach dziewięćdziesiątych XX wieku. Od powieści Kratka knjiga (Krótka książka) z 1993 roku w utworach serbskiego pisarza pojawia się wyrazisty zwrot ku referencjalności, będący następstwem wydarzeń społeczno-politycznych (wybuch wojny i rozpad Jugosławii), ale poniekąd także spóźnionej reinterpretacji postmodernistycznej poetyki (przejście z autotematyzmu w stronę zaangażowania), która miała miejsce już wcześniej w literaturach zachodnich (Nowak-Bajcar 91-123). Powieść Brat, wydana po raz pierwszy w 2008 roku, sytuuje się bardzo daleko od wczesnych utworów Albahariego, w których zmagania z formą narracyjną jawiły się jako wartość autoteliczna. Chociaż autotematyzm jest obecny również w tej powieści, należy go interpretować jako krańcowo umowny i ironiczny lub nawet, jak sugeruje Tatjana Rosić, w powieści Brat "spektakl wydarzania się płci” oraz „wydarzania się ludu” należy „wbrew wszelkim wskazówkom dotyczącym sposobu czytania powieści postmodernistycznej rozumieć krańcowo mimetycznie" (Rosić 349), ponieważ wydarzyło się w niej całkiem konkretne zabójstwo, które katalizuje bunt, słabo reprezentowany w serbskim społeczeństwie. 
Zgiął się, powiedział Filip, i dotknął czoła Alisy. Robert otworzył oczy i szepnął „Dlaczego mi to robisz?". Krople krwawej śliny opryskały jego brodę. Co ma teraz z nim zrobić, zastanawiał się Filip, chociaż znał odpowiedź jeszcze zanim postawił to pytanie Nie był na niego zły, powiedział, przynajmniej nie w ten najprostszy, prymitywny sposób, znany każdemu, chociaż - wierzył, że się z nim zgodzę - miał wiele powodów do złości, z tym jednym najważniejszym, jakim był przyjazd Roberta, który zniszczył mu życie, negatywnie wpłynął na jego karierę, co więcej, doprowadził go do sytuacji, w której dosłownie musi walczyć o to, by zachować ducha (Albahari 179).

Mamy tu do czynienia z typową drobnomieszczańską troską o własną pozycję społeczną i własne życie, której towarzyszy milczące przyzwolenie na zabójstwo Innego, „mniej wartościowego” Innego. Chociaż po obdukcji ciała Roberta/ Alisy pojawia się informacja, że można było zapobiec tragicznemu zakończeniu, gdyby pacjent został wcześniej zawieziony do szpitala, Filip, jak tłumaczy narratorowi, nie ma ,żadnych wątpliwości, że może być winny” (Albahari 188), oczekując przy tym od niego zrozumienia iod samego początku upragnionego androcentrycznego i bratocentrycznego „przyjacielskiego uścisku” (Albahari 188). Nie uzyskawszy od narratora spodziewanej odpowiedzi, w Filipie dokonuje się pewna przemiana, częściowe uznanie własnej winy, które wiedzie go ku opisanej w zakończeniu powieści metamorfozie:

Kiedy idzie, powiedział, musi ciągle się odwracać, gdyż wydaje mu się, że odpadają z niego części, jak gdyby składał się klocków, z których dzieci układają różne cuda, a kiedy jeden się poluzuje, wszystko może się rozpaść. Zamilkł, wstał z krzesła, na którym siedział, a kiedy ruszył w moją stronę, faktycznie się obejrzał. Dopiero wtedy dostrzegłem, że rzeczywiście się zmienił. Umknęło mi to, gdy mówił, gdyż za słowami można się schować jak za parawanem, ale kiedy milczy, człowiek jest pozbawiony kryjówki, nic go nie osłania. Zrobił jeszcze krok, dwa i zatrzymał się przede mną. Stał, jakby na coś czekał, potem westchnął i powoli ruszył w kierunku drzwi mojego mieszkania, otworzył je i wyszedł na klatkę schodową. Poczułem podmuch przeciągu i pospieszyłem do przedpokoju, ale drzwi już się zatrzasnęły i pozostało mi tylko przekręcić klucz. (Albahari 193)

Po tym jak Filip opuszcza mieszkanie, zabierając ze sobą swoją opowieść queer, anonimowy narrator dosłownie i symbolicznie zamyka drzwi na klucz. Taki powieściowy finał można odczytać dwojako - z jednej strony jako zakończenie opowieści, od której narrator się dystansuje, uczestniczy w niej z niechęcią i nie akceptuje przyjacielskiej zażyłości z Filipem, z drugiej zaś - można uznać, że narrator dostrzega dokonującą się w Filipie przemianę i przeczuwając to, co kryje się za jego milczeniem, nie chce być wspólnikiem zbrodni, a zatem implicytnie wyraża swoje etyczne stanowisko. Bez względu na to, które odczytanie uznamy za właściwe, ważne jest, aby dostrzec formalne znaczenie decyzji Albahariego co do wyboru typu narratora. W odróżnieniu od powieści Geneta Matka Boska Kwietna, w której 
narrator usiłuje nadać szlachetnego charakteru męskości queer, poddanej systemowi więziennego nadzorowania i karania, czyniąc z bohaterów "kwiaty zła”, narrator Albahariego (wraz z głównym bohaterem i gośćmi restauracji Brioni uosabiającymi głos większości) stara się, niekiedy niepostrzeżenie, czasem otwarcie, wdrożyć w życie wspomniany represyjny system, eliminując męskość queer jako coś niechcianego w serbskim społeczeństwie, jako ciało obce ${ }^{7}$. Albahari podąża tropem Brechta - obojętna relacja z tragicznej historii zbrodni (w przypadku nieco bardziej wrażliwego narratora zaangażowanie emocjonalne musiałoby uwidocznić się $\mathrm{w}$ formie narracji) ma wzbudzić efekt obcości (efekt $\mathrm{V})^{8}$, czyli pewną postawę etyczną, będącą wyrazem potrzeby otwarcia się na wolność.

Nawet gdy wolność zostaje zamknięta pod kluczem, przed nami rozciąga się utopijny horyzont wolności, który jesteśmy w stanie dostrzec pomimo istniejących mechanizmów represji. Jego linia została $w$ obu powieściach wyznaczona przez narrację. Za jej pomocą Genet obdarza bohaterów swojej powieści, poddanych więziennemu systemowi nadzorowania i karania, nieocenzurowaną wolnością ich queer, podczas gdy Albahari brutalnie zderza czytelnika z utopią wolności, do której wiedzie droga zdecydowanych obywatelskich działań.

\section{Ttumaczenie z jezzyka serbskiego: Aleksandra Wojtaszek. Przektad przejrzała: Sylwia Nowak-Bajcar}

\section{BIBLIOGRAFIA}

Aćin, Jovica. „Blesak Ženeovog dela kao živog vulkana”. Posłowie: Žan Žene. Bogorodica od Cveća. Beograd: Službeni glasnik, 2012. S. 251-257.

Albahari, David. Brat. Beograd: Stubovi kulture, 2009.

Brecht, Bertolt. „Die Straßenszene. Grundmodell einer Szene des epischen Theaters (1940)“. Werke. Große kommentierte Berliner und Frankfurter Ausgabe, Hrsg. Werner Hecht, Frankfurt am Main: Suhrkamp, 1993. S. 370-381.

7 Autor używa sformułowania (na)strano telo, chcąc podkreślić dwuznaczność wynikającą z faktu, ze słowo nastrano oznacza w języku serbskim 'perwersyjny', zaś strano - 'obcy'. Oddanie tej gry językowej za pomocą jednego słowa nie jest możliwe w przekładzie na język polski - przyp. łłum.

8 Oto jedno z wielu objaśnień Brechta dotyczących efektu $\mathrm{V}\left({ }_{\text {, }} \mathrm{V}^{\prime \prime}\right.$ pochodzi od niemieckiego słowa Verfremdung - 'obcość'), w którym najlepiej staje się widoczny „ideologiczny” wymiar takiego zabiegu: „technika takiego portretowania międzyludzkich interakcji społecznych, w których zostają one oznaczone jako coś uderzającego, jako coś, co wymaga objaśnienia, co nie może być uznane za pewnik ani potraktowane jako naturalne. Celem tego efektu jest umożliwienie obserwatorowi

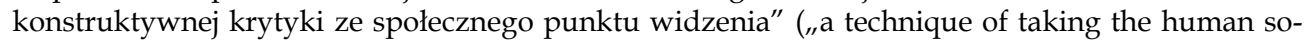
cial incidents to be portrayed and labelling them as something striking, so mething that calls for explanation, is not to be taken for granted, not just natural. The object of this 'effect' is to allow the spectator to criticize constructively from a social point of view") (Brecht 98). 
Cixous, Hélène. „Śmiech Meduzy”. Przeł. Anna Nasiłowska. Konsultacja: Marek Bienczyk. Teksty Drugie 4/5/6 (1995). S. 147-166.

Derrida, Jacques. The Politics of Friendship. Transl. George Collins. London-New York: Verso, 2005.

Derrida, Jacques. „Dar, podatak, datumi”. Politike prijateljstva. Przeł. Ivan Milenković, Beograd: Beogradski krug, 2001. S. 9-13.

Genet, Jean. Matka Boska Kwietna. Przeł. Krzysztof Zabłocki. Warszawa: Tenten, 1994.

Jagose, Annamarie. Queer teorija: An introduction. New York: University Press, 1996.

Đoković, Nikola. „Brat Davida Albaharija - ispovest o (brato)ubistvu”. Sarajevske sveske 39-40 (2012). S. 134-155.

Freccero, Carla. Queer/Early/Modern. Durham and London: Duke University Press, 2006.

Foucault, Michel. Nadzorować i karać. Narodziny więzienia. Przeł. Tadeusz Komendant. Warszawa: Wydawnictwo Aletheia, 2009.

Lane, Christopher. „The Crimes of Virtue and the Love of Aversion: Sade, Genet, and the Christian Right". American Imago 4 (1996). S. 325-351.

Mančić, Aleksandra. „O čemu piše Žan Žene”. Posłowie: Žan Žene. Čudo ruže. Beograd: Službeni glasnik, 2013. S. 339-350.

Nowak-Bajcar, Sylwia. Mapy czasu. Serbska proza postmodernistyczna wobec wyzwań epoki. Kraków: Wydawnictwo Uniwersytetu Jagiellońskiego, 2010.

Perišić, Igor. „Reprezentacija homoseksualnog identiteta u Zlatnom runu Borislava Pekića i Staklencu Uroša Filipovića: Mainstream i/ili off". Teorije i politike roda: Rodni identiteti u knjižeonostima i kulturama jugoistočne Evrope. Ured. Tatjana Rosić. Beograd: Institut za književnost i umetnost, 2008. S. 387-404.

Rosić, Tatjana. (Anti)utopije tela: Reprezentacija maskuliniteta u savremenoj srpskoj prozi. Beograd: Institut za književnost i umetnost, 2014. 